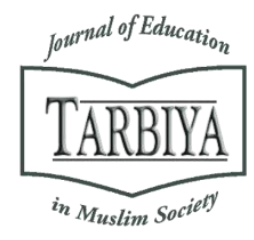

Available online at TARBIYA: Journal of Education in Muslim Society Website:

http://journal.uinjkt.ac.id/index.php/tarbiya

TARBIYA: Journal of Education in Muslim Society, 5(2), 2018, 145-154

\title{
DEVELOPING SOCIAL INTELLIGENCE SCALE INSTRUMENTS FOR VOCATIONAL SCHOOL (SMK) STUDENTS
}

\author{
Awaluddin Tjalla \\ State University of Jakarta, Indonesia \\ E-mail: awaluddin.tjalla@gmail.com
}

Received: $26^{\text {th }}$ June 2018; Revised: $25^{\text {th }}$ November 2018; Accepted: $28^{\text {th }}$ December 2018

\section{Abstract}

This study aims to develop scale instruments that can be used to identify potentials in relation to the readiness of students to enter the workforce with very high commissioning characteristics. The study was conducted at SMK Negeri 57 South Jakarta, using a simple random technique for 135 students. Data were analyzed using a Confirmatory Factor Analysis (CFA) with the SEM (Structural Equation Modeling) method. The findings of the study show that: (1) Steps to develop a valid and reliable social intelligence scale instrument are; synthesis, construct, type of instrument, instrument lattice, instrument items, theoretical validation, trial, calculate validity and reliability, instrument assembly. (2) The dimensions and indicators underlying the concept of social intelligence scale are; component of social awareness (dimensions of basic empathy, dimensions of alignment, empathic accuracy, social understanding), components of social facilities (dimensions of synchronization, self-appearance, influence, concern). (3) Calculation of instrument validity using total gain correlation formula, Pearson product moment with a significance level of $0.05 ; \mathrm{r}$ table $=0.176$. (4) Instrument reliability is $\alpha=0.858$.

Keywords: instrument; social intelligence scale; vocational school

\section{Abstrak}

Penelitian ini bertujuan untuk mengembangkan instrumen skala yang dapat digunakan untuk mengidentifikasi potensi dalam relasinya dengan kesiapan siswa untuk memasuki dunia kerja dengan karakteristik commissioning yang sangat tinggi. Penelitian dilakukan di SMK Negeri 57 Jakarta Selatan, menggunakan teknik acak sederhana untuk 135 siswa. Data dianalisis menggunakan Confirmatory Factor Analysis (CFA) dengan metode SEM (Structural Equation Modeling). Temuan penelitian menunjukkan bahwa: (1) Langkah-langkah untuk mengembangkan instrumen skala kecerdasan sosial yang valid dan dapat diandalkan adalah; sintesis, konstruk, jenis instrumen, instrumen kisi, item instrumen, validasi teoretis, percobaan, menghitung validitas dan reliabilitas, perakitan instrumen. (2) Dimensi dan indikator yang mendasari konsep skala kecerdasan sosial adalah; komponen kesadaran sosial (dimensi empati dasar, dimensi keselarasan, akurasi empatik, pemahaman sosial), komponen fasilitas sosial (dimensi sinkronisasi, penampilan diri, pengaruh, kepedulian). (3) Perhitungan validitas instrumen menggunakan rumus korelasi total gain, Pearson product moment dengan tingkat signifikansi 0,05; $r$ tabel $=0,176$. (4) Keandalan instrumen adalah $\alpha=0,858$.

Kata kunci: instrument; skala kecerdasan sosial; sekolah kejuruan

How to Cite : Tjalla, A. (2018). Developing Social Intelligence Scale Instruments for Vocational School (SMK) Students. TARBIYA: Journal of Education in Muslim Society, 5(2), 145-154. doi:10.15408/tjems.v5i2.10622.

Permalink/DOI: http://dx.doi.org/10.15408/tjems.v5i2.9475 


\section{Introduction}

Globalization, affect many aspects of human's life, including education. Even secondary education have to follow more rapid, complex, and global revolution. Information on materials and all news in schools all over the world have changed rapidly. Instruments used to communicate, collaborate, and adapt to the changes of the $21^{\text {st }}$ century is also increasingly complex and difficult to predict.

The results of international studies, such as PIRLS (Progress in International Reading Literacy Study), TIMSS (Trends in International and Science Study), and PISA (Program for International Student Assessment) show the ability of Indonesian children in the fields of reading, mathematics, and science. which is far behind compared to other countries. In this context, students at the level of secondary education are required to have the complete skills and knowledge, including: communication skills; (2) critical and creative thinking; (3) information/digital literacy; (4) inquiry/reasoning skills; (5) interpersonal skills; (6) multicultural/multilingual literacy; (7) problem solving; and (8) technological skills (Wagner, 2008).

Buzan (2002) states that social intelligence is the ability of individuals to "get along" and connect with others around them. Individuals who have social intelligence who can use their body and brain to communicate and "read" other people. According to Buzan, to be a successful person in difficult social challenges, individuals need social intelligence relating to: the ability to listen to others, be able to make light conversations with other people, be able to understand other people's feelings, be able to "sell" ideas to others, Having a positive attitude towards yourself and others, and being able to create good closeness with others. Furthermore Albrecht (2006), put forward the concept of human intelligence which is termed "multiple intelligence". Albrecht develops human intelligence into six categories, namely: abstract, social, practical, emotional, aesthetic, and kinesthetic intelligence. Where according to him social intelligence is "the ability to get along with other people and invite them to work together". Similarly, Khilstrom and Cantor define social intelligence as a store of knowledge about the social world, regulating relationships with others, and the ability to deal with people with different backgrounds by refuting (Sternberg \& Kaufman, 2012).

Indonesia consists of various tribes or religions or so-called heterogeneous societies. Being in a heterogeneous community environment that is prelude, not only is intelligence needed but social intelligence is needed, this is similar to what is stated in the Quran Sura An-Nahl verse 93 "And if Allah wills, He will make you one people (only), but God deceives whom he wants and gives guidance to whom he wants. And indeed you will be asked what you have done. "[QS An Nahl: 93]. So it is impossible for us to create a homogeneous society on this earth, what happens is a heterogeneous society. (Umar, 2017)

Vocational high school (SMK) as one type of education in the national education system has a peculiarity which lies in the availability of productive subjects and life skills learning programs. In the implementation, life skill education and productive subjects should be oriented to: (1) the principles of supply driven becomes the principles of market driven, (2) life skills and environmental insights, (3) vocational high school should be able to work independently (self-employed) or be ready to work, (4) the use of broad-based learning approach, competency-based learning approach, and production-based learning approach (Kementerian Pendidikan dan Kebudayaan, 2014). 


\section{Instrument}

Not a few students who are smart in school, fail in real life, unable to interrupt with their environment to be able to socialize well in the environment so as to provide benefits for themselves and their lives. Important, there are other factors beyond intellectual intelligence that support individual success in achieving goals and successes in life. So, the problems that can be denied are: (1) Factors that influence student achievement, (2) The importance of social intelligence for someone, (3) Dimensions and indicators related to social intelligence, (4) How to compile instruments measuring social intelligence scale, (5) validity of measuring instruments of social intelligence scale, and (6) reliability of measuring instruments of social intelligence scale. Instruments, which can make full use of these surplus resources of intelligent instruments. (Huang, 2018).

From the consideration of the problems that concern the above, this research is focused on developing social excellence scale instruments for students of Vocational High School 57 South Jakarta which can be detailed as follows: (1) Dimensions and indicators underlying the social intelligence of Vocational students, Instrument validity the social intelligence scale of vocational students, (3) Reliability of instruments of social naturalist intelligence scale of SMK students.

Bayar (2018) the precision of response and partial adjustment coefficients can be enhanced by raising the strength of instruments. Saini (2018), the strength of evidence for each instrument based on methodological quality.

Through this research, it is expected to produce a social intelligence scale instrument that meets the requirements of readability, validity and reliability. The results of the research on the development of social intelligence scale instruments can provide significant contributions, including:

1) Make a theoretical contribution in explaining and developing instruments of social intelligence both at different levels of growth and development in different regions.

2) This research can be used as one of the instruments to conduct guidance and counselling services for students. Development of counselling programs that are right on target will make acceptability of Counseling Guidance services in schools better and also help counsellors to account for the implementation of Guidance Counseling services for relevant parties (stakeholders).

3) The results of this study are expected to help measure the social intelligence of students at the Secondary Education level which can also be used as a consideration for decision makers or education providers, such as the Ministry of National Education of the Republic of Indonesia, Educational Foundations, and other community components that assist Secondary Education in compiling relevant policies and implementing them to support education development to improve education at the level of Secondary Education.

4) The results of the study can be used at the level of Secondary Education as one of the instruments for conducting formative tests or evaluations, within the framework of understanding students' social intelligence.

5) The results of this study can be used by teachers as a measure of students' social intelligence learning in teaching and learning activities carried out in schools. 


\section{Validity}

The method of testing instrument validity in research on the development of these instruments was carried out in two construct validation analyzes, namely theoretical and construct validity. Theoretical trials of social intelligence scale instruments conducted by Vocational Schools are conducted through expert judgment that discusses the assessment of each question or question related to psychological aspects, namely cognitive, affective and psychomotor aspects. In order for these tools to be of value, their psychometric properties need to be confirmed to ensure reliability and validity (Almanasreh, 2018).

This discusses the opinion of Soeprijanto (2010), namely testing the non empirical validity of test testing, completeness test and conformity test. Suitability test for testing suitability between variables, indicators and descriptors. Three main points were developed by the panellists, namely: (1) conformity of dimensions with developed variables, (2) suitability of indicators with variables developed, and (3) suitability of descriptors with developed work indicators. Next, determine the construct validity of the empirical trial used analysis with factor analysis techniques through the use of the SEM method with the software (application) LISREL 8.70 program.

Fitz Patrick (2018) validity is dependent on the purpose and context of the research, and refers to conclusions that are based on particular methods used to address validity threats that are pertinent to the particular research. To check for construct validity, the instrument should be tested against other tools found in the literature that assess the same or a similar construct, and it is recommended that the magnitude of such correlations should be stated apriori. (Rodrigues, et. al, 2018).
Content validity/construct is done by expert judgment. In this study, the expert testing process was carried out by 2 experts namely instrumentation experts and social intelligence experts. (1) Requirements for instrumentation experts have at least a master's degree in the fields of Guidance and Counseling or Psychology and have experience in the field of instrumentation, as well as conducting research or training on instrumentation.

Requirements for social intelligence experts with at least a master's degree in the fields of Guidance and Counseling or Psychology, and having experiences in social or logistical fields, such as conducting research or training on social development or students. Both experts assessed social intelligence from the compatibility between variables with sub-variables, subvariables with indicators, indicators with descriptors and conformity descriptors with questions/items.

After being validated by the panellists, social intelligence scale instruments were tested. Test of empirical validity is done by testing instruments to respondents. To determine the validity of each item by analyzing the data from the trial results. The trial results were implemented to determine the construct validity of the instrument using factor analysis. This analysis was carried out to avoid "expert bias", obtained two questions in factor analysis, namely: (1) exploratory approval (exploratory factor analysis), and (2) confirmatory registration (confirmatory factor analysis). In the research on the development of the social intelligence scale, the construct validity test was used by analyzing Confirmatory Factor Analysis (CFA) through SEM modelling.

\section{Reliability}

Megan, et. al (2018) reliability is the consistency of an assessment tool to produce stable results with each use. Reliability test may 
be performed at several levels with different purposes. (Ruidong, 2017).

Reliability test is done by determining internal consistency. The formula used to determine internal consistency is Cronbach Alpha. The selection of reliability testing techniques is because the items contained in the scale of social intelligence have a characteristic that is political (Cohen, 2009). Reliability testing is done using the help of the Microsoft Excel program. Reliability refers to an instrument's ability to produce consistent findings within or between different testers over time. (Butler, et al., 2018).

\section{Methods}

This study generally aims to create a social intelligence scale measurement tool that can be used by students of SMK Negeri 57 South Jakarta. In particular, this study has the following objectives, namely: (1) Describe the dimensions and indicators underlying the concept of social intelligence; (2) Constructing a social intelligence scale that has validity; and (3) Constructing a social intelligence scale measuring instrument that has reliability.

The development of this social intelligence scale uses a development model which generally consists of six stages, namely: (1) developing conceptual and operational definitions of scale instruments, (2) determining measurement methods, (3) constructing items, (4) testing/analyzing scale items, (5) revising, and (6) publishing instruments.

The sampling technique in this study was random sampling (simple random sampling). The number of samples or respondents in this study were 135 people. The sample used was a class XI student from a program in South Jakarta State Vocational High School 57 randomly selected. This sample was taken in early
December 2017 until the end of December 2017.

The making of social intelligence scale measuring instruments uses two dimensions, namely social awareness and spectrum of social facilities. Social awareness includes: (1) primal empathy, (2) attunement, (3) empathic accuracy and (4) social cognition while the spectrum of social facilities includes: (1) synchrony, (2) selfpresentation, (3) influence and (4) concern.

Testing of social intelligence scale instruments of vocational students using validity tests which include content validity (construct) and empirical validity, and reliability testing. While the development of the instrument uses (1) Parameter of Measuring Results (Scaling); (2) Item Writing; and (3) Expert Review.

\section{Results and Discussion}

\section{Component of Social Awareness}

\section{Validity and Reliability Test Results of Basic Empathy Dimensions}

The researcher test whether the seven items are unidimensional, meaning that they only measure basic empathy. From the results of the Confirmatory Factor Analysis (CFA) analysis, which is done by a onefactor model where measurement errors on some freed items correlate with each other, a model that is fit with Chi-Square $=11.94$, $\mathrm{df}=13$, p-value $=0.53250$, and RMSEA $=$ 0,000 . So that the researchers no longer need to re-modify the existing model.

Having obtained the p-values 0.05 , it can be stated that a model with one factor is acceptable, meaning that all items only measure one factor, namely basic empathy. The following is a table of factor loadings and $t$-values to see instrument validity and reliability on the dimensions of basic 
empathy using Confirmatory Factor Analysis (CFA).

Table 1. Content of Basic Empathy Factors

\begin{tabular}{lllll}
\hline $\begin{array}{l}\text { No. } \\
\text { Item }\end{array}$ & Lambda & $\begin{array}{l}\text { Standard } \\
\text { Error }\end{array}$ & $\begin{array}{l}\text { t- } \\
\text { value }\end{array}$ & Signifikan \\
\hline 44 & 1,00 & 0,06 & 16,31 & $\sqrt{ }$ \\
65 & $-0,33$ & 0,08 & $-3,92$ & \\
67 & 0,18 & 0,09 & 2,15 & $\sqrt{ }$ \\
68 & $-1,00$ & 0,06 & - & \\
& & & 16,32 & \\
69 & $-0,10$ & 0,09 & $-1,19$ & \\
71 & 0,18 & 0,09 & 2,15 & $\sqrt{ }$ \\
72 & 0,13 & 0,09 & 1,50 & \\
\hline
\end{tabular}

Validity and Reliability of Test Results of Alignment Dimension

The researcher tested whether the 14 items were unidimensional, meaning that they only measured alignment. From the results of the Confirmatory Factor Analysis (CFA) analysis conducted with a one-factor model in several tests and/or modifications to the model where the measurement error on some freed items correlated with one another, then a model that was fit with ChiSquare $=69.66$ was produced. $, d f=56, p$ value $=0.10378$, and the value of $R M S E A=$ 0.043 .

Table 2. Load Alignment Factors

\begin{tabular}{lllll}
\hline $\begin{array}{l}\text { No. } \\
\text { Item }\end{array}$ & Lambda & $\begin{array}{l}\text { Standard } \\
\text { Error }\end{array}$ & $\begin{array}{l}\text { t- } \\
\text { value }\end{array}$ & Signifikan \\
\hline 1 & 0,12 & 0,07 & 1,67 & \\
3 & $-0,18$ & 0,08 & $-2,10$ & \\
4 & $-0,56$ & 0,07 & $-7,55$ & \\
8 & 0,49 & 0,07 & 6,63 & $\sqrt{ }$ \\
9 & 0,60 & 0,07 & 8,04 & $\sqrt{ }$ \\
10 & 0,82 & 0,09 & 9,13 & $\sqrt{ }$ \\
20 & $-0,31$ & 0,07 & $-4,24$ & \\
21 & 0,16 & 0,07 & 2,20 & $\sqrt{ }$ \\
27 & 0,81 & 0,08 & 10,41 & $\sqrt{ }$ \\
29 & $-0,76$ & 0,07 & - & \\
& & & 10,31 & \\
30 & $-0,62$ & 0,08 & $-3,07$ & \\
31 & $-0,23$ & 0,08 & $-3,07$ & \\
33 & 0,55 & 0,09 & 6,18 & $\sqrt{ }$ \\
70 & 0,45 & 0,08 & 5,68 & $\sqrt{ }$ \\
\hline
\end{tabular}
acceptable, meaning that all items only measure one factor, namely alignment. The following is a table of factor loadings and tvalues to see instrument validity and reliability on the Alignment dimension using Confirmatory Factor Analysis (CFA).

\section{Validity and Reliability of Test Results of Accuracy Dimension}

Researchers tested whether the 15 items were unidimensional, meaning that they only measured empathic accuracy. From the results of the Confirmatory Factor Analysis (CFA) analysis conducted with a one factor model, after several tests and/or modifications to the model where measurement errors on some freed items correlated with each other, then a model that was fit with Chi-Square $=84.99$ was produced. $, \mathrm{d} f=68, \mathrm{p}$-value $=0.07979$, and the value of $R M S E A=0.043$. So that researchers no longer need to re-modify the existing model.

Table 3. Contents of empathic accuracy factors

\begin{tabular}{lllll}
\hline $\begin{array}{l}\text { No. } \\
\text { Item }\end{array}$ & Lambda & $\begin{array}{l}\text { Standard } \\
\text { Error }\end{array}$ & $\begin{array}{l}\text { t- } \\
\text { value }\end{array}$ & Signifikan \\
\hline 2 & 0,13 & 0,09 & 1,36 & \\
5 & 0,47 & 0,09 & 5,18 & $\sqrt{ }$ \\
22 & 0,56 & 0,09 & 6,45 & $\sqrt{ }$ \\
23 & 0,00 & 0,10 & $-0,02$ & \\
28 & 0,43 & 0,10 & 4,36 & $\sqrt{ }$ \\
39 & $-0,34$ & 0,10 & $-0,19$ & \\
41 & 0,34 & 0,09 & 3,79 & $\sqrt{ }$ \\
43 & $-0,02$ & 0,10 & $-0,19$ & \\
48 & $-0,41$ & 0,09 & $-4,56$ & \\
50 & 0,07 & 0,10 & 0,69 & \\
53 & $-0,67$ & 0,09 & $-7,89$ & \\
57 & $-0,09$ & 0,09 & $-0,94$ & \\
59 & $-0,17$ & 0,11 & $-1,57$ & \\
63 & $-0,46$ & 0,10 & $-4,74$ & \\
64 & 0,10 & 0,10 & 1,03 & \\
\hline
\end{tabular}

After getting p-value> 0.05 it can be stated that a model with one factor can be accepted, meaning that all items only measure one factor, namely empathic 
accuracy. The following is a table of factor loadings and t-values to see the validity and reliability of instruments in empathic accuracy dimension using Confirmatory Factor Analysis (CFA).

\section{Validity and Reliability of Test Results Social Understanding Dimension}

The researchers tested whether the 14 items were unidimensional, meaning that they only measured social understanding. From the results of the Confirmatory Factor Analysis (CFA) analysis conducted with a one-factor model, after several tests and/or modifications to the model where the measurement error on some freed items correlated with each other, then a model that was fit with Chi-Square $=80.68$ was produced., $d f=64$, $p$-value $=0.07767$, and the value of $R M S E A=0.044$.

After getting a $p$-value> 0.05 it can be stated that a model with one factor is acceptable, meaning that all items only measure one factor, namely social understanding. The following is a table of factor load and t-values to see the validity and reliability of instruments in the dimension of social understanding by using Confirmatory Factor Analysis (CFA).

Table 4. Content of Social Understanding Factors

\begin{tabular}{lllll}
\hline $\begin{array}{l}\text { No. } \\
\text { Item }\end{array}$ & Lambda & $\begin{array}{l}\text { Standard } \\
\text { Error }\end{array}$ & $\begin{array}{l}\text { t- } \\
\text { value }\end{array}$ & significant \\
\hline 6 & 0,60 & 0,09 & 6,83 & $\sqrt{ }$ \\
7 & 0,59 & 0,08 & 6,96 & $\sqrt{ }$ \\
11 & $-0,31$ & 0,09 & $-3,36$ & \\
12 & $-0,71$ & 0,08 & $-8,79$ & \\
13 & $-0,51$ & 0,09 & $-5,69$ & \\
16 & $-0,26$ & 0,09 & $-2,72$ & \\
45 & $-0,70$ & 0,08 & $-8,60$ & \\
51 & 0,19 & 0,10 & 2,06 & $\sqrt{ }$ \\
54 & 0,19 & 0,10 & 1,99 & $\sqrt{ }$ \\
73 & $-0,32$ & 0,09 & $-3,44$ & \\
74 & $-0,70$ & 0,08 & $-8,63$ & \\
76 & $-0,29$ & 0,09 & $-3,18$ &
\end{tabular}

\begin{tabular}{lllll}
\hline $\begin{array}{l}\text { No. } \\
\text { Item }\end{array}$ & Lambda & $\begin{array}{l}\text { Standard } \\
\text { Error }\end{array}$ & $\begin{array}{l}\text { t- } \\
\text { value }\end{array}$ & significant \\
\hline 78 & $-0,29$ & 0,09 & $-3,18$ & \\
79 & 0,59 & 0,08 & 6,98 & $\sqrt{ }$ \\
\hline
\end{tabular}

\section{Social Facilities component}

\section{Validity and Reliability of Test Results of Synchronization Dimension}

The researcher tested whether the ten items were unidimensional, meaning that they only measured synchronization. From the results of the Confirmatory Factor Analysis (CFA) analysis conducted by a onefactor model, after several tests and/or modifications to the model where the measurement error on some freed items correlated with each other, then a model that was fit with Chi-Square $=24.46, \mathrm{df}=$ $34, p$-value $=0.88572$, and the value of RMSEA $=0.000$. So that researchers no longer need to re-modify the existing model.

After getting the $p$-value 0.05 it can be stated that a model with one factor is acceptable, meaning that all items only measure one factor, Synchrony. The following is a table of factor loadings and tvalues to see instrument validity and reliability on the synchronous dimension by using Confirmatory Factor Analysis (CFA).

Table 5. Synchronous load factors

\begin{tabular}{lllll}
\hline $\begin{array}{l}\text { No. } \\
\text { Item }\end{array}$ & Lambda & $\begin{array}{l}\text { Standard } \\
\text { Error }\end{array}$ & $\begin{array}{l}\text { t- } \\
\text { value }\end{array}$ & Signifikan \\
\hline 46 & 0,25 & 0,15 & 1,74 & \\
47 & 0,21 & 0,15 & 1,45 & \\
62 & 0,37 & 0,15 & 2,52 & $\sqrt{ }$ \\
75 & $-0,35$ & 0,15 & $-2,41$ & \\
77 & $-0,96$ & 0,16 & $-6,12$ & \\
80 & 0,30 & 0,15 & 2,06 & $\sqrt{ }$ \\
81 & $-0,09$ & 0,15 & $-0,60$ & \\
83 & 0,37 & 0,15 & 2,52 & $\sqrt{ }$ \\
84 & $-0,32$ & 0,15 & $-2,17$ & \\
86 & 1.01 & 0,16 & 6,31 & $\sqrt{ }$ \\
\hline
\end{tabular}




\section{Self Appearance}

The researcher tested whether the 14 items were unidimensional, meaning that they only measured themselves. From the results of the Confirmatory Factor Analysis (CFA) analysis conducted by a one factor model, after several tests and / or modifications to the model where the measurement error on some freed items correlated with each other, a model that was fit with Chi-Square $=73.37$ was produced, $d f=61$, $p$-value $=0.13309$, and the value of RMSEA $=$ 0.039 . So that researchers no longer need to remodify the existing model.

After obtaining p-values 0.05 it can be stated that a model with one factor is acceptable, meaning that all items only measure one factor, namely Self Appearance. The following is a table of factor load and t-values to see the validity and reliability of instruments in the Self Appearance dimension using Confirmatory Factor Analysis (CFA).

Table 6. Content of Self Appearance Factors

\begin{tabular}{lllll}
\hline $\begin{array}{l}\text { No. } \\
\text { Item }\end{array}$ & Lambda & $\begin{array}{l}\text { Standard } \\
\text { Error }\end{array}$ & $\begin{array}{l}\text { t- } \\
\text { value }\end{array}$ & $\begin{array}{l}\text { Signifikan } \\
14\end{array}$ \\
\hline 15 & 0,54 & 0,10 & 5,53 & $\sqrt{ }$ \\
15 & 0,11 & 2,85 & $\sqrt{ }$ \\
19 & 0,18 & 0,10 & 1,82 & \\
24 & 0,13 & 0,11 & 1,23 & \\
25 & $-0,43$ & 0,10 & $-4,45$ & \\
26 & $-0,48$ & 0,09 & $-5,09$ & \\
32 & $-0,21$ & 0,10 & $-2,02$ & \\
40 & 0,37 & 0,10 & 3,69 & $\sqrt{ }$ \\
52 & $-0,38$ & 0,09 & $-4,05$ & \\
55 & 0,37 & 0,10 & 3,89 & $\sqrt{ }$ \\
56 & 0,16 & 0,10 & 1,56 & \\
58 & $-0,22$ & 0,10 & $-2,11$ & \\
82 & 0,32 & 0,10 & 3,03 & $\sqrt{ }$ \\
85 & 0,54 & 0,10 & 5,65 & $\sqrt{ }$ \\
\hline
\end{tabular}

\section{Influence}

The researcher tested whether the 14 items were unidimensional, meaning that they only measured influence. From the results of the Confirmatory Factor Analysis (CFA) analysis, it was carried out with a one-factor model, after several tests and / or modifications to the model where measurement errors on some items were released correlated with each other, a model that is fit with Chi-Square $=80.71, \mathrm{~d} f=66, \mathrm{p}$-value $=$ 0.10516 , and RMSEA $=0.041$. So that researchers no longer need to re-modify the existing model.

After getting the $p$-value> 0.05 it can be stated that a model with one factor is acceptable, meaning that all items only measure one factor, namely Influence. The following is a table of factor loadings and t-values to see the validity and reliability of instruments on the Influence dimension using Confirmatory Factor Analysis (CFA).

Table 7. Content of Influence Factors

\begin{tabular}{lllll}
\hline $\begin{array}{l}\text { No. } \\
\text { Item }\end{array}$ & Lambda & $\begin{array}{l}\text { Standard } \\
\text { Error }\end{array}$ & $\begin{array}{l}\text { t- } \\
\text { value }\end{array}$ & significant \\
\hline 17 & 0,17 & 0,09 & 1,87 & \\
18 & $-0,29$ & 0,09 & $-3,19$ & \\
35 & $-0,07$ & 0,09 & $-0,71$ & \\
42 & 0,14 & 0,09 & 1,53 & \\
87 & 0,98 & 0,07 & 13,58 & $\sqrt{ }$ \\
89 & 0,13 & 0,09 & 1,40 & \\
90 & $-0,22$ & 0,09 & $-2,36$ & \\
91 & $-0,02$ & 0,09 & $-0,26$ & \\
92 & 1,02 & 0,07 & 14,28 & $\sqrt{ }$ \\
93 & $-0,42$ & 0,09 & $-4,77$ & \\
94 & 0,45 & 0,09 & 5,16 & $\sqrt{ }$ \\
95 & $-0,11$ & 0,09 & $-1,24$ & \\
98 & 0,32 & 0,09 & 3,51 & $\sqrt{ }$ \\
100 & $-0,06$ & 0,09 & $-0,65$ & \\
\hline
\end{tabular}

The researcher tested whether the 14 items were unidimensional, meaning that they only measured caring. From the results of the Confirmatory Factor Analysis (CFA) analysis, it was carried out with a one-factor model, after several tests and / or modifications to the model where measurement errors on some items were released correlated with each other, a model that is fit with Chi-Square $=72.87, d f=56, p$-value $=$ 0.06435 , and RMSEA $=0.047$. So that researchers no longer need to re-modify the existing model.

After getting the $p$-value> 0.05 it can be stated that a model with one factor is acceptable, meaning that all items only measure one factor, 
namely Influence. The following is a table of factor loadings and t-values to see the validity and reliability of instruments on the Caring dimension using Confirmatory Factor Analysis (CFA).

Table 8. Content of Concern Factors

\begin{tabular}{lllll}
\hline $\begin{array}{l}\text { No. } \\
\text { Item }\end{array}$ & Lambda & $\begin{array}{l}\text { Standard } \\
\text { Error }\end{array}$ & $\begin{array}{l}\text { t- } \\
\text { value }\end{array}$ & significant \\
\hline 34 & 0,27 & 0,09 & 2,84 & $\sqrt{ }$ \\
36 & 0,37 & 0,09 & 4,11 & $\sqrt{ }$ \\
37 & 0,62 & 0,08 & 7,48 & $\sqrt{ }$ \\
38 & 0,20 & 0,09 & 2,19 & $\sqrt{ }$ \\
49 & 0,25 & 0,09 & 2,76 & $\sqrt{ }$ \\
60 & $-0,24$ & 0,09 & $-2,61$ & \\
61 & 0,90 & 0,08 & 11,80 & $\sqrt{ }$ \\
66 & 0,42 & 0,09 & 4,65 & $\sqrt{ }$ \\
88 & $-0,68$ & 0,08 & $-8,23$ & \\
96 & 0,00 & 0,09 & $-0,01$ & \\
97 & $-0,09$ & 0,09 & $-0,99$ & \\
99 & $-0,44$ & 0,09 & $-4,91$ & \\
101 & $-0,35$ & 0,09 & $-3,94$ & \\
\hline
\end{tabular}

\section{Pearson's Total Product Moment Correlation}

From the results of theoretical validation, that is through expert or expert examination, obtained 101 items of instruments of social intelligence scale students of SMK Negeri 57 South Jakarta. Improvements were made to the instrument in terms of language as many as 34 instrument items. After being revised, then doubling is done for instrument testing (empirical validation).

Instrument testing was given to 135 class XII students from various skill programs found in SMK Negeri 57 South Jakarta. Based on the results of the trial data, an analysis is then carried out to test and / or know the item validity (validity). Item validity test is done using the correlation formula of Pearson's total product moment with the number of samples/respondents $\mathrm{n}=135$ and level significance $(\alpha=0.05: r$ table $=0.176)$. The conclusion of the test results of the item validity is as follows:
Table 9. Item status

\begin{tabular}{lll}
\hline Status & Nomor Butir Instrument & Total \\
\hline Valid & $4,14,19,20,23,36,37,38,39$, & 40 \\
& $44,45,46,47,48,49,50,53$, & items \\
& $54,55,56,57,58,59,60,61$, & \\
& $63,64,65,66,71,73,76,77$, & \\
& $78,80,81,82,86,91$, dan 98 & \\
& $\left(\right.$ Kriteria: $\mathrm{r}_{\text {hitung }}>\mathrm{r}_{\text {tabel }}(0,176)$ pada & \\
& $\alpha 0,05)$ & \\
Drop & $1,2,3,5,6,7,8,9,10,11,12$, & 60 \\
& $13,15,16,17,18,21,22,24$, & Items \\
& $25,26,27,28,29,30,31,32$, & \\
& $33,34,35,40,41,42,43,51$, & \\
& $52,62,67,68,69,70,72,74$, & \\
& $75,79,83,84,85,87,88,89$, & \\
& $90,92,93,94,95,96,97,99$, & \\
& 100, dan 101 & \\
& $\left(\right.$ Kriteria: $\mathrm{r}_{\text {hitung }}>\mathrm{r}_{\text {tabel }}(0,176)$ pada & \\
& $\alpha 0,05)$ & \\
\hline
\end{tabular}

\section{Reliability Test}

After testing the validity, then calculating the reliability of the instrument. Based on the results of the reliability analysis of the instruments of social intelligence scale students of SMK Negeri 57 South Jakarta using the Alpha Cronbach reliability coefficient formula obtained reliability coefficient of $0.858>0.80$, which means that the reliability level of the social intelligence scale of students of SMK Negeri 57 South Jakarta is high. With a reliability coefficient value of 0.858 , it means that the instrument of social intelligence scale students of SMK Negeri 57 South Jakarta has high reliability.

\section{Conclusion}

Based on the results and discussion of the study, it can be concluded that (1) the steps to develop instruments of social intelligence scale students of SMKN 57 South Jakarta are valid and reliable, which is based on synthesis of theories about social intelligence, then a concept is examined and constructs are formulated, based on the construct developed dimensions and indicators, set the type of instrument, made instrument lattice, wrote instrument items, 
carried out theoretical validation through expert examination, test implementation try the instrument, test construct validity and calculate reliability, instrument assembly. (2) The dimensions and indicators that underlie the concept of social intelligence scale of students of SMKN 57 South Jakarta are components of social awareness (dimensions of basic empathy, dimensions of alignment, empathic accuracy, social understanding), components of social facilities (dimensions of synchronization, selfappearance, influence, concern).

The results of the trial are then performed validity analysis using the correlation formula of Pearson's total product moment with a significance level of $\alpha 0.05$; $\mathrm{r}$ table $=0.176$. (4) The results of the calculations show high reliability in the instrument of social intelligence scale students of SMK Negeri 57 South Jakarta, namely $\alpha=0.858$. The category is high because $0.858>0.80$ (Traub, 1994).

Based on this description, it can be concluded that the research on the development of social intelligence scale instruments of students of SMK Negeri 57 South Jakarta has produced good or quality instrument items and can be expressed as standard and feasible instruments for use in other relevant studies.

\section{References}

Albrecht, K. (2006). Social intelligence: The new science of success. Josseey-Bass.

Almanasreh, E., Rebekah Moles, Timothy F. (2018). Chen Evaluation Of Methods Used For Estimating Content Validity, Research in Social and Administrative Pharmacy, vol. 15(2), pages 214-221.

Bayar, O. (2018). Weak Instruments And Estimated Monetary Policy Rules Journal of Macroeconomics, . 58(C), 308-317

Butler, Mark W. et. al. (2018). Reliability and Accuracy of The Brachial Plexus
Neurodynamic Test. Journal of Hand Therapy.

Buzan, T. (2002). The power of social intelligence: 10 ways to top into your social genius. New York: HarperCollins Publishers Inc.

Cohen, J. (2009), Philosophy, Politics, Democracy, Cambridge, Mass., Harvard University Press.

Kementerian Pendidikan dan Kebudayaan. (2014). Peta Jalan Kurikulum 2013. Jakarta: Pusat Informasi dan Hubungan Masyarakat, Kemendikbud RI.

Megan M, et. al, (2018). Test-Retest Reliability Of Longitudinal Task-Based Implications For Developmental Studies, Developmental Cognitive Neuroscience. Vol. 33, pages 17-26.

Rodrigues, Mirela S., et. al, (2018). Rapid offices train assessment (ROSA): Crosscultural validity, reliability and structural validity of the Brazilian-Portugue seversion, Applied Ergonomics, vol. 75, pages 143-154.

Ruidong, D. (2017). GUO Chun, Researches and Investigation On Manufacturers' Reliability Test Data of Electronic Parts. Energy Procedia.

Saini, et all. (2019). Systematic Review and Critical Appraisal Of Child Abuse Measurement Instruments. Psychiatry Research. V (272), 106-113.

Soeprijanto, (2010). Pengukuran Kinerja Guru Praktek Kejuruan: Konsep dan Teknik Pengembangan Instrumen. Jakarta: CV. Tursina.

Sternberg, R.J., Kaufman, S.B. (2012). Thecambrigde handbook of intelligence. New York: Cambridge University Press.

Traub, Ross E. (1994). Reliability for the social sciences: Theory and applications. Thousands Oaks, California: SAGE Publications, Inc

Umar, N. (29 Januari 2019). Citing Internet Sources URL https://www.beritasatu.com/ nasional/434811-presiden-dan-pimpinan-dprterpaku-dengar-tausiah-ini.html.

Wagner, T. (2008) The Global Achievement Gap. New York: Basic Books.. 